\title{
Enrolment Expansion in China: The Large Class Phenomenon
}

\author{
Yiming Shan \\ School of Foreign Languages, Zhaoqing University, Zhaoqing, China \\ Email:symhelen@hotmail.com
}

How to cite this paper: Shan, Y. M. (2020) Enrolment Expansion in China: The Large Class Phenomenon. Open Journal of Social Sciences, 8, 1-13.

https://doi.org/10.4236/jss.2020.88001

Received: June 24, 2020

Accepted: August 3, 2020

Published: August 6, 2020

Copyright (c) 2020 by author(s) and Scientific Research Publishing Inc. This work is licensed under the Creative Commons Attribution International License (CC BY 4.0).

http://creativecommons.org/licenses/by/4.0/ (c) (i)

Open Acces

\begin{abstract}
The worldwide expansion of education has brought the issue of large classes to researchers' attention. In China, following the university enrolment expansion since 1999, an increasing number of Chinese educators are faced with the issue of managing large classes efficiently. However, studies on the enrollment policy and the subsequent large class phenomenon are scarce. This study primarily examined enrolment expansion in Chinese higher education by analyzing policy documents and existing literature on both enrolment expansion and large class phenomenon. Additionally, the current study amplified the need for future research on issues pertaining to large classes that can help teachers, school managers, and policymakers devise effective strategies for addressing problems affecting teaching practice.
\end{abstract}

\section{Keywords}

Policy Analysis, Enrolment Expansion, Large Class Teaching, China

\section{Introduction}

Because of the high demand for higher education and the subsequent educational expansion, large classes have become a common worldwide phenomenon at the university level (Lipinge, 2013). In China, the policy of increased enrolment in higher education was proposed in the Third National Conference on Education in 1999 to promote university education and invigorate China through developments in science and education. In observance of the guidelines, higher education institutes successfully accomplished enrolment enlargement, leading 
to the drastic increase in enrolment figures from $3,408,764^{1}$ in 1998 to $4,085,874^{2}$ in 1999. Particularly, the ratio of teachers to students in Chinese higher education was $1: 16.3$ in 2006 , which was noticeably higher than the best ratio (1:14) in developed countries (Yan \& Chang, 2008).

Researchers (e.g., Fan, 2003; Lipinge, 2013; Peng, 2005) have acknowledged that the enrolment initiatives have created insurmountable problems for both students and teachers, thereby leading to a degradation in the quality of teaching and learning. Therefore, an examination of the enrolment expansion policy and the issues engendered by large classes warrant attention. Such studies will contribute to the indigenous literature focused on the Chinese context and explain the developments in Chinese higher education. Furthermore, they will provide insights into effective means of enhancing learning and teaching under the university enrolment expansion policy.

\section{Literature Review}

\subsection{Interpretations of Large-Sized Classes}

Many educational researchers have attempted to quantify large classes (e.g., Azhar, 2004; Todd, 2006); however, no unanimous agreement on the class size could be achieved. Todd (2006) concluded that the concept of a large class is a loosely defined one with various interpretations depending on the contexts. Heppner (2007) defined a large class as one that is "taught in a lecture hall with fixed seats and has a number of students greater than the number whose names you can reasonably learn by semester's end." (p. 2) Table 1 shows different researchers' estimation of the numbers of students in a large class in different educational contexts.

Table 1 shows how the class size of a large class is interpreted differently on the basis of researchers' subjective judgment pertaining to specific teaching contexts. For instance, the minimum number of students in large classes is 50 in China, while in Kenya the number is 40, and in the United Kingdom, it is only 25. According to Coleman (1989), the assessment of the ideal number of students in a large class can be subjectively influenced and is dependent on the usual class size of the teaching staff concerned. Furthermore, the figures in Table 1 highlight that the size of large classes in developing countries starkly contrast that in developed countries. This is because the number of learners in developing countries is considerably more than that in developed countries. For instance, the size of a large class ranges from 40 to 150 students (40 in Kenya and 150 in China) in developing countries, whereas large classes comprise $>40$

${ }^{1}$ Source: Changes in Undergraduate Enrolment in 1998 published by the Ministry of Education of the People's Republic of China.

http://www.moe.gov.cn/publicfiles/business/htmlfiles/moe/moe 573/200505/7674.html (Accessed 27/03/13)

${ }^{2}$ Source: Changes in Undergraduate Enrolment in 1999 published by the Ministry of Education of the People's Republic of China.

http://www.moe.gov.cn/publicfiles/business/htmlfiles/moe/moe 563/200505/7788.html (Accessed 27/03/13) 
Table 1. Numbers of students in large classes.

\begin{tabular}{|c|c|c|}
\hline Author & No. of Students & Teaching context \\
\hline $\mathrm{Gu}(2009)$ & 50 & China \\
\hline Jimakorn \& Singhasiri (2006) & $35-100$ & Not mention \\
\hline Lei (2015) & around 80 & China \\
\hline $\operatorname{Li}(2008)$ & $60-150$ & China \\
\hline Mulryan-Kyne (2010) & $300-1000$ & Not mention \\
\hline $\begin{array}{c}\text { Nakabugo, Opolot-Okurut, Ssebbunga, } \\
\text { Manni, \& Byamugisha (2008) }\end{array}$ & 70 & Uganda \\
\hline Nakabugo et al. (2008) & above 40 & Japan \\
\hline Nakabugo et al. (2008) & above 60 & Developing countries \\
\hline Nakabugo, Albert \& Maani, (2006) & 40 & Kenya \\
\hline O’Sullivan (2006) & above 35 & US \\
\hline Smith \& Warburton (1997) & $25-30$ & UK \\
\hline Ur (1996) & $40-50$ & Not mention \\
\hline Wang (2002) & $70-80$ & China \\
\hline Yang \& Yang (2006) & 60 & China \\
\hline Yang (2008) & around 60 & China \\
\hline Yuan (2004) & 50 & China \\
\hline
\end{tabular}

students in Japan, >35 students in the United States, and between 25 and 30 students in the United Kingdom. Gu and Wang's (2017) statement that teaching English to large classes is common in developing countries highlights the phenomenon of crowded classes in these countries.

\subsection{Features of Large Classes}

Todd (2006) suggested that massive classes are likely to present various challenges to the teaching and learning of English. Thus, familiarity with the characteristic features of large classes is critical for teachers to improve teaching quality in these classes. The following sections discuss both advantages and disadvantages of large classes.

Regarding the advantages of teaching large classes, some previous studies have demonstrated that a large student count can promote effective teaching and learning. McLeod (1989) argued that teaching a large class can reduce instructor expenses because it effectively utilizes time, resources, and talent. Furthermore, some researchers (e.g., Li \& Wang, 2008; Peng, 2007) have acknowledged that large classes provide students an environment that is conducive for the exchange of information and learning experiences, thereby broadening the scope of their 
learning. Additionally, the competition among learners is quite robust in large classes, which creates a competitive atmosphere that ultimately increases students' learning motivation (Yuan, 2004).

Many previous studies have highlighted the shortcomings of large classes (e.g., Al-Jarf, 2006; Gu \& Wang, 2017; Herington \& Weaven, 2008). LoCastro (1989) classified the problems pertaining to teaching large classes into three categories, namely pedagogical problems, management-related problems, and affective problems. The following section reviews the problems related to large class teaching from these three aspects.

First, regarding pedagogical problems, some educators (e.g., Al-Jarf, 2006; Cleek, 2005; Locastro, 2001) have reported that teachers find it difficult to attend to each student in large classes. After examining teachers' responses to a questionnaire assessing the impact of large classes, Locastro (2001) extracted the following five instructional problems:

- Increased difficulties in executing speaking, reading, and writing tasks.

- Difficulties in monitoring student learning and providing feedback.

- Problems with individualizing lessons to suit learners' needs.

- Difficulties in establishing communicative tasks.

- Tendency to avoid demanding activities.

Additionally, Christensen (1994) highlighted two major problems encountered during large class teaching, difficulty in moving around the classroom and attending to all students. Furthermore, Western researchers have identified the following pedagogical issues affecting teachers of large classes: difficulties in promoting students' learning motivation (Herington \& Weaven, 2008), difficulties in designing assignments and awarding grades in accordance with students' individual characteristics (Cleek, 2005), and being equipped with only a limited range of teaching methods (McLeod, 1989). Additionally, Hayes (1997) suggested that teachers find it considerably challenging to "handle the workload, and thus, resort to using no papers and no essay exams, and rely only on the multiple-choice exam." (p. 85)

Similarly, Chinese researchers have reported that teachers of large classes find delivering good teaching quality difficult because the teaching approaches and materials at their disposal cannot satisfy the learning needs of all students (e.g., Li, 2011; Niu, 2016). Additionally, designing activities that can involve all students and is a challenging task (Wang \& Yan, 2011), as is communicating or interacting with all students (Li, 2011; Yang, 2008). Most importantly, teachers of large classes have to shoulder a heavy workload, especially when evaluating students' assignments (Gu \& Wang, 2017; Yang, 2008). Yang (2008) explained that,

Teachers always complain that they feel frustrated when checking students' work, and they are anxious about giving students feedback on time. For reducing the burden of checking assignments of all students, teachers have to randomly select and examine the work of some of the students. This definitely reduces the effectiveness of learning because teachers cannot get fa- 
miliar with students' learning outcomes.

Second, regarding the management problems associated with large class teaching, the effective management of large classes presents educators with a critical challenge. Locastro (2001) listed the following problems that teachers of large classes encounter:

- Pair and group work often cumbersome to execute

- Noise level high, affecting neighboring classes

- Difficulties in attending to all students during class time

- Discipline problems more acute

Relevant literature revealed that managing the chaos in large classes is challenging for teachers (e.g., Benbow, Mizrachi, Oliver, \& Said-Moshiro, 2007; Locastro, 2001). Therefore, teachers have to invest more effort into resolving discipline issues and grading students' assignments rather than into improving their teaching quality.

Additionally, researchers have highlighted that teachers of large classes struggle with time management. Wilson (cited in Benbow et al., 2007) claimed that "large classes take a toll on the teacher's ability to manage time, requiring more time to be devoted to instructions, task management, and behavioral management, thus leaving less time for actual instruction." (p. 6)

Moreover, in China, a lot of teachers' time is spent on addressing discipline problems (Niu, 2016), which hinders the achievement of learning effectiveness (Wang \& Yan, 2011). Niu (2016) reported that,

In the large classes, it is inevitable that some of the students become distracted, and even take initiatives unrelated to learning such as speaking with the desk mate in a whisper, using mobile phones, sleeping, and eating snacks. For ensuring adherence to the teaching schedule, teachers must ignore the students who are distracted, and this may lead to discipline problems in the classroom.

Third, regarding affective issues concerning large classes, Wright (2005) opined that "the affective domain is central to learning and its management, a central concern in teaching and learning." (p. 149) Particularly, Locastro (2001) highlighted the following affective problems:

- Difficulties in learning students' names.

- Impossibility of establishing a good rapport with students.

- Concern for weaker students who may get lost.

- Crowd phenomenon: students' not listening to the teacher and other students.

- Problems in assessing students' interests and moods.

(pp. 494-495)

Moreover, Nakabugo et al. (2008) indicated that the feeling of anonymity pervading the class and distance between teachers and students affects large class teaching. Additionally, Chinese researchers noted that students' confidence and learning interests can weaken as a result. Yang (2008) demonstrated that, 
Most Chinese students are the only child in the family and are very sheltered by their parents. Therefore, it is easy for these children to become self-centred. In the large class setting, teachers cannot interact with each individual student. In particular, these self-centred students feel ignored and consequently lose interest in learning.

Because of the abovementioned pedagogical problems, management concerns, and affective issues, teachers face more problems in organizing their classes and controlling their students in large classes than in small classes.

\section{Methodology}

Policy analysis refers to "a process through which we identify and evaluate alternative policies or programs that are intended to lessen or resolve social, economic, or physical problems." (Patton \& Sawicki, 1993: p. 21) This study performed a policy analysis to examine the impact of enrolment expansion policy in mainland China's higher education. Two types of policy analysis were adopted to conduct a systematic evaluation of the policy. One was descriptive policy analysis that was used for analyzing "past policies," and the other was prescriptive policy analysis that was adopted to "recommend actions" (Patton \& Sawicki, 1993: p. 24).

The analysis process was designed by referring to the rational model presented by Fallon \& Rublik $(2011)^{3}$ and Weinmer \& Vining (1992) $)^{4}$, both of which mainly focus on problem analysis and solution analysis. As Fallon \& Rublik (2011) mentioned, "rational models of policy analysis are useful because they deal with the incremental and multi-staged nature of policy development." (p. 4)

\section{Findings}

\subsection{Enrolment Expansion in China}

Before 1999, the number of students enrolling in higher education institutes was small and increased gradually. To contribute to China's economic development, in the beginning of 1999, some economists argued that acceleration of higher education development should be adopted as an important strategy to increase the domestic demand for education. Thus, in June 1999, the State Council approved the policy presented by the Ministry of Education of China, namely the Action Plan for Reinvigorating Education in the 21 st Century, to increase student enrolment in higher education institutions and expand domestic consumption. As seen in Figure 1, a drastic increase was noted in the enrolment figures since 1999. Wang (2009: p. 1) stated that "the numbers just kept climbing"

${ }^{3}$ Fallon \& Rublik (2011) concluded that "the rational models of policy analysis focus on understanding policy formation," which contain "problem definition; clarification of values, goals, and objectives; identification of options; selection of courses of action; evaluation of a course of action; and modification of policies." (p. 3)

${ }^{4}$ Weimer \& Vining (1992) presented a seven-step rationalist mode: "understanding the problem, choosing and explaining relevant goals and constraints, choosing a solution method, choosing evaluation criteria, specifying policy alternatives, evaluating and recommending actions." (p. 3) 


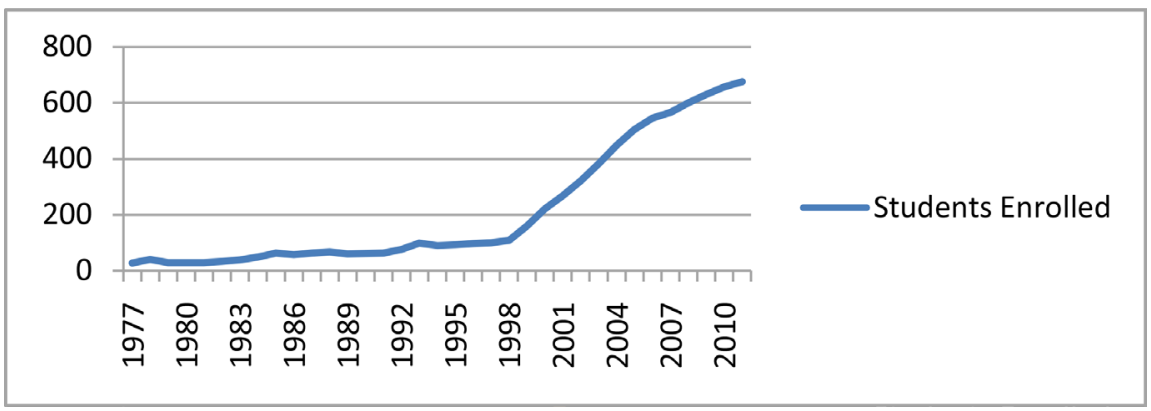

Figure 1. Students enrolled in higher education institutions. Source: Baidu Encyclopedia. (n.d.). Retrieved from http://baike.baidu.com/view/990168.htm

following the implementation of the enrollment policy. For example, in 2011, the enrolment figure of higher education institutes was 6.75 million, which was six times more than the figure in 1998 (Figure 1).

Additionally, problems emerged both before and after the implementation of the policy. Concerning the process of policymaking, Yan \& Chang (2008) argued that the implementation of the enrolment enlargement policy was rather fast. Particularly, there was a gap of only four months between policy approval and implementation. According to Yuan's (2000) statement, because of time constraints, the supporting polices for enrolment expansion could not be formulated and implemented. According to Innes (cited in Patton \& Sawicki, 1993), the knowledge of users (such as decision makers or clients) is likely to influence their decision-making. However, as highlighted by Yan \& Chang (2008), this policy's policymakers mainly comprised State Council's economists and officers, and educators or people from the educational administrative department were largely excluded. Therefore, the manner in which the enrolment expansion policy was devised and implemented seemed inappropriate for the Chinese educational context.

Furthermore, a fresh set of problems surfaced in China after the policy implementation. According to Azhar (2004: p. 1), "with the rapid development in all spheres of life, the need for mass education arose, which resulted in the emergence of large classes." However, the large classes created to accommodate the increased enrolment presented challenges for Chinese educators. Additionally, Gu \& Wang (2017) emphasized that teachers faced numerous obstacles during large class teaching in China. The following section will examine potential solutions to the problem engendered by enrolment expansion.

\subsection{Solutions to Challenges of Enrolment Expansion and Large Class Teaching}

The aforementioned literature reveals that enrolment expansion has drastically changed the teacher-to-student ratio and significantly increased the workload of teachers of large classes. Chinese educational researchers (e.g., Peng, 2005; Yan \& Chang, 2008; Zhang, 2010) have reported that enlarging enrolment led to a degradation in the teaching quality. 
For effective policymaking, policymakers should make adjustments in course of the implementation. As Younis and Davidson (cited in Patton \& Sawicki, 1993) stated, "policies often change during implementation" and "implementers shape policy at every stage of the policymaking process." (p. 308) Yan \& Chang (2008) acknowledged that the more perspectives or knowledge policymakers have, the more practical is the policy implementation. Therefore, involving educators in the formulation of the enrolment expansion policy is critical. Furthermore, teachers, especially novice teachers, should be provided with specialized teacher training for managing large classes. Fan (2003) and Shi \& Li (2001) highlighted that offering long-term training to teachers is necessary in that it can enhance their professional knowledge and support their teaching.

Additionally, reducing the maximum number of students that can be enrolled in a class could attenuate the consequences of the crowded class phenomenon (Al-Jarf, 2006). However, as Bahanshal (2013) claimed, reducing the class size is rather impossible in developing countries. Additionally, Markee (1997) mentioned that "innovation must also engage teachers in the more abstract tasks of developing their methodological skills and changing their ideas about what constitutes good teaching." (p. 54) Educators (e.g., Azhar, 2004; Li, 2011; Nakabugo et al., 2008; Song, 2009) have shifted their research focus from analyzing the effects of class size to exploring effective methods of addressing challenges and innovative strategies for improving teaching quality in large classes. Some teaching strategies for addressing problems engendered by large classes, categorized into three aspects on the basis of LoCastro's (1989) classification are presented in Table 2.

Table 2 shows how a majority of the suggestions focus on management problems and pedagogical issues to mitigate the drawbacks of large classes. O'Sulliven (2006) highlighted that any examination of the teaching or management strategies for large classes should consider the teaching context. Furthermore, Ndethiu, Masingila, Coonor, Khatete, \& Heath (2017: p. 6) explained that "context, specifically culture, plays a very significant role in determining a teacher's degree of tolerance for large classes." Otienoh (cited in Ndethiu et al., 2017) suggested that "class size effects vary depending on grade level, student characteristics, nature of the programme, teaching approach, and other interventions." (p. 8) Therefore, familiarity with students and information on vital aspects, such as their learning needs and language-proficiency levels, constitute a key component of large class teaching. As explained by Niu (2016), teacher's attention greatly facilitates learning motivation. By contrast, students lose interest in learning if they feel ignored by teachers.

\section{Conclusion}

With the rapid growth in student population following the implementation of the enrolment expansion policy, examining the issues engendered by large classes in China is necessary and useful. Yang (Cited in Mu, 2006) predicted that "college 
Table 2. Teaching strategies for managing large classes.

\begin{tabular}{|c|c|c|}
\hline & Strategies & Researcher(s) \\
\hline \multirow{3}{*}{$\begin{array}{l}\text { Management } \\
\text { concerns }\end{array}$} & $\begin{array}{l}\text { Get instructions right and clear; } \\
\text { Create positive learning environment; } \\
\text { Involve students in active learning; } \\
\text { Reduce workload of teacher }\end{array}$ & Wu, 1993 \\
\hline & Reward students for being present & Michelson, 2003 \\
\hline & Run group work & $\begin{array}{l}\text { Dong \& Cao, 2006; Li, 2011; } \\
\text { Peng, 2007; Song, } 2009\end{array}$ \\
\hline \multirow{3}{*}{$\begin{array}{l}\text { Affective } \\
\text { issues }\end{array}$} & Use audio-visual aids in ELT classes & Azhar, 2004 \\
\hline & $\begin{array}{l}\text { Get to know students' names } \\
\text { and their needs }\end{array}$ & $\begin{array}{l}\text { Dong \& Cao, 2006; Hayes, 1997; } \\
\text { Nakabugo et al, 2008; Peng, 2007; } \\
\text { Song, 2009; Wu, } 1993\end{array}$ \\
\hline & Move around the classroom & $\begin{array}{l}\text { Dong \& Cao, 2006; } \\
\text { Nakabugo et al, } 2008\end{array}$ \\
\hline \multirow{6}{*}{$\begin{array}{l}\text { Pedagogical } \\
\text { problems }\end{array}$} & $\begin{array}{l}\text { Personalise feedback; } \\
\text { Get the students to listen; } \\
\text { Help students create connections; } \\
\text { Exploit stories and examples; } \\
\text { Take participatory lecture; } \\
\text { Use of questions }\end{array}$ & $\begin{array}{c}\text { Azhar, } 2004 \\
\text { Azhar, 2004; } \\
\text { O’Sullivan, } 2006\end{array}$ \\
\hline & Use two-way communication & Li \& Wang, 2008; Michelson, 2003 \\
\hline & Vary the rhythm of the class & Michelson, 2003 \\
\hline & Multimedia technology & Peng, 2007; Song, 2009 \\
\hline & Adopt games, competitions and role-play & Peng, 2007 \\
\hline & Chang from teacher-centred to student-centred & Li, 2011; Ma, 2001; Song, 2009 \\
\hline
\end{tabular}

enrollment will increase in the future because China's population is still growing." (p. 1). Therefore, this paper performed a policy analysis to examine the problems and solutions related to the implementation of the enrolment expansion policy in China. The study results revealed that college enrolment leads to the large class phenomenon that makes teaching considerably challenging. For solving the problems caused by enrolment expansion, the expansion policy must be adjusted and effective teaching strategies for large classes must be explored in terms of the particularities of the teaching context.

The results of this policy analysis can assist policy makers and researchers attenuate the issues faced by teachers of large classes in China. Teachers are suggested to consider management-related, affective, and pedagogical concerns when teaching large classes. This article's limitation was that it adopted only a policy analysis to examine the large class phenomenon caused by university enrolment expansion. Future studies are recommended to investigate the consequences of enrolment expansion through different approaches for a more in-depth under- 
standing of the large class phenomenon.

\section{Fund}

2019 Research Project of Zhaoqing Education Development Institute: Textbook Evaluation and Development (ZQJYY2019018); 2019 Foreign Language Teaching and Research in Universities (Basic Education): Teachers' Beliefs about Textbook Evaluation (2019051501).

\section{Conflicts of Interest}

The author declares no conflicts of interest regarding the publication of this paper.

\section{References}

Al-Jarf, R. (2006). Large Student Enrollments in EFL Programs: Challenges and Consequences. The Asian EFL Journal Quarterly, 8, 4-34.

Azhar, M. A. (2004). Management of Large Size English Language Teaching Classes: A Study at High School Level in District Abbottabad, Pakistan. Islamabad: National University of Modern Languages.

Bahanshal, D. A. (2013). Large Classes on English Teaching and Learning in Saudi Secondary Schools. English Language Teaching, 6, 49-59.

https://doi.org/10.5539/elt.v6n11p49

Benbow, J., Mizrachi, A., Oliver, D., \& Said-Moshiro, L. (2007). Large Class Size in the Developing World: What Do We Know and What Can We Do? Phnom Penh: American Institute for Research under the EQUIP1LWA. http://www.equip123.net

Christensen, T. (1994). Large Classes and Their Influence on Language Teaching. Journal of Hokusei Junior College, 30, 121-129.

Cleek, M. A. (2005). Challenging High Potential Students in Large Classes: A Hurdles Approach. College Teaching Methods \& Styles Journal-Second Quarter, 1, 85-92. https://doi.org/10.19030/ctms.v1i2.5232

Coleman, H. (1989). How Large Are Large Classes? Lancaster: Lancaster-Leeds Language Learning in Large Classes Research Project.

Dong, Y. H., \& Cao, E. L. (2006). How to Tackle the Problems in Large Classes. Journal of Xingtai Polytechnic College, 23, 38-40.

Fallon, G., \& Rublik, N. (2011). Second-Language Education Policy in Quebec: A Critical Analysis of the Policy of English as a Compulsory Subject at the Early Primary Level in Quebec. TESL Canada Journal, 28, 90-104.

Fan, X. H. (2003). Influences on College English Teaching Caused by Enrollment Enlarging and Research on the Way to Problems. Henan Social Sciences, 11, 184-186.

Gu, M., \& Wang, Q. (2017). Teaching Large Classes in Chinese High Schools: What Do Teachers Say and Do? Chinese Journal of Applied Linguistics, 40, 145-229. https://doi.org/10.1515/cjal-2017-0009

$\mathrm{Gu}, \mathrm{X}$. Y. (2009). Applications of Autonomous Learning \& Cooperative Learning in Large Class ELT. Journal of Nanchang College, 82, 92-94.

Hayes, D. (1997). Helping Teachers to Cope with Large Classes. ELT Journal, 51, 106-116. https://doi.org/10.1093/elt/51.2.106

Heppner, F. H. (2007). Teaching the Large College Class: A Handbook for Instructors 
with Multitudes. San Francisco, CA: Jossey-Bass.

Herington, C., \& Weaven, S. (2008). Action Research and Reflection on Student Approaches to Learning in Large First Year University Classes. The Australian Educational Researcher, 35, 111-134. https://doi.org/10.1007/BF03246292

Jimakorn, P., \& Singhasiri, W. (2006). Teachers' Beliefs Concerning Large-Class English Teaching at the University Level. KMUTT Journal of Language Education, 9, 13-23.

Lei, K. (2015). The Principals of Teaching in Heterogen Classes in Secondary Schools. Journal of Chongqing College of Electronic Engineering, 24, 124-127.

Li, K. (2008). Teaching College English to a Large Class: Problems and Remedies. Sino-US English Teaching, 5, 13-18.

Li, Y. (2011). Exploration of Participatory Teaching-Strategies of Participatory Teaching in Middle School Large English Class. Overseas English, 2, 21-24.

Li, Y. X., \& Wang, X. Q. (2008). On Class Control Tactics of Large Class Teaching in Universities. Journal of Hengshui University, 10, 103-105.

Lipinge, S. M. (2013). Challenges of Large Class Teaching at the University: Implications for Continuous Staff Development Activities (pp. 105-120). http://people.math.sfu.ca/ vjungic/Lipinge.pdf

Locastro, V. (1989) Large size classes: The situation in Japan. UK: Lancaster-Leeds Language Learning in Large Classes Research Project.

Locastro, V. (2001). Teaching English to Large Classes: Large Classes and Student Learning. TESOL Quarterly, 35, 439-496. https://doi.org/10.2307/3588032

Ma, J. B. (2001). Innovation in Large Class Teaching in Higher Education: Learning from the Western Classroom Teaching Model. Journal of Henan Institute of Science and Technology, 4, 61-62.

Markee, N. (1997). Managing Curricular Innovation. Cambridge: Cambridge University Press.

McLeod, N. (1989). What Teachers Cannot Do in Large Classes. Lancaster: Lancaster-Leeds Language Learning in Large Classes Research Project Report No. 7.

Michelson, C. (2003). Meeting the Challenges of Larger Classes. Toronto: Faculty of Arts \& Science, University of Toronto.

http://www.kau.edu.sa/GetFile.aspx?id=275784\&fn=Challenges\%20of\%20large\%20clas ses.pdf

Mu, X. Q. (2006). Higher Education Ends Grand Expansion Era. The Central People's Government of the People's Republic of China.

http://english.gov.cn/2006-05/12/content 278668.htm

Mulryan-Kyne, C. (2010). Teaching Large Classes at College and University Level: Challenges and Opportunities. Teaching in Higher Education, 15, 175-185.

https://doi.org/10.1080/13562511003620001

Nakabugo, M. C., Albert, B., \& Maani, J. S. (2006). Investigating Strategies for Improving Teaching and Learning in Large Classes for Basic Education Support in Uganda. Hiroshima: Hiroshima University.

Nakabugo, M. C., Opolot-Okurut, C., Ssebbunga, C. M., Maani, J. S., \& Byamugisha, A. (2008). Large Class Teaching in Resource-Constrained Contexts: Lessons from Reflective Research in Ugandan Primary Schools. Journal of International Cooperation in Education, 11, 85-102.

Ndethiu, S. M., Masingila, J. O., Connor, M. K. M., Khatete, D. W., \& Heath, K. L. (2017). Kenyan Secondary Teachers' and Principals' Perspectives and Strategies on Teaching 
and Learning with Large Classes. Africa Education Review, 14, 58-86. https://doi.org/10.1080/18146627.2016.1224573

Niu, L. Y. (2016). The Problems and Strategies for Large Classes Teaching in the Secondary Schools. English Teachers, 16, 66-68.

O'Sullivan, M. C. (2006). Teaching Large Classes: The International Evidence and a Discussion of some Good Practices in Ugandan Primary Schools. International Journal of Educational Development, 26, 24-37.

Patton, C. V., \& Sawicki, D. S. (1993). Basic Methods of Policy Analysis and Planning (2nd ed.). Upper Saddle River, NJ: Prentice-Hall.

Peng, J. H. (2005). The Advantages and Disadvantages of College Expansion and Its Implications for Educational Management in Higher Education. Forum on Contemporary Education, 3, 74-76.

Peng, N. (2007). Strategies in Teaching English to Large Classes in the Universities. USChina Education Review, 401, 66-69.

Shi, Y. Q., \& Li, W. H. (2001). The Influences of Enrolment Expansion on Teaching Quality and the Strategies for the Problems. Journal of Nanjing Medical University (Social Sciences), 4, 269-271.

Smith, P., \& Warburton, M. (1997). Strategies for Managing Large Classes: A Case Study. Professional Development in Education, 23, 253-265. https://doi.org/10.1080/13674589700200019

Song, Z. (2009). Current Situation and Tactics of College English Large Class Teaching in China. Journal of Tianjin Institute of Financial and Commercial Management, 10, 65-66.

Todd, R. W. (2006). Why Investigate Large Classes. KMUTT Journal of Language Education, 9, 1-12.

Ur, P. A. (1996). Course in Language Teaching: Practice and Theory. Cambridge: Cambridge University Press.

Wang, F. (2002). Viewpoints on Solving Problems in Large Class Teaching. Journal of Liaocheng University, 5, 84-86.

Wang, J., \& Yan, X. (2011). Literature Reviews on Teaching English to Large Classes in College in the Recent Decade Years in China. Education Research Monthly, 11, 105-106.

Weimer, D. L., \& Vining, A. R. (1992). Policy Analysis: Concepts and Practice (2nd ed.). Upper Saddle River, NJ: Prentice-Hall.

Wright, T. (2005). Classroom Management in Language Education. Basingstoke: Palgrave Macmillan. https://doi.org/10.1057/9780230514188

Wu, H. Q. (1993). A Probe into Autonomous Learning in Tertiary Large Class English Teaching. Journal of Shanxi University of Finance and Economics (Higher Education), 14, 56-59.

Yan, G. F., \& Chang, Q. H. (2008). Enrolment Expansion in Higher Education: Policy Making, Implementation, Influences and Adaptation. Modern University Education, 3, 70-75.

Yang, S. J., \& Yang, N. C. (2006). On the Issues and Countermeasures in the English Teaching under Several Classes Integration. Forum on Contemporary Education, 8, 129-131.

Yang, S. X. (2008). The Problems and Strategies for Large Classes Teaching. Journal of Basic English Education, 10, 42-46.

Yuan, X. (2004). A Study of College English Teaching in Large Class. Journal of Pingdingshan Institute of Technology, 13, 75-77. 
Yuan, Z. G. (2000). Policy Analysis of Chinese Education. Beijing: Jiaoyu Kexu.

Zhang, Y. M. (2010). The Influences of College Expansion on Teaching Quality. Medical Information, 6, 1564-1565. 